\title{
Agritourism: Toward a conceptual framework for industry analysis
}

\author{
Lisa C. Chase a * \\ University of Vermont
}

Mary Stewart b

Oregon State University

Brian Schilling c

Rutgers University

\author{
Becky Smith d \\ Mississippi State University \\ Michelle Walk e \\ Michigan State University
}

Submitted January 17, 2018 / Revised January 31, 2018 / Accepted February 13, 2018 /
Published online April 2, 2018
Citation: Chase, L. C., Stewart, M., Schilling, B., Smith, B., \& Walk, M. (2018). Agritourism:
Toward a conceptual framework for industry analysis. Journal of Agriculture, Food Systems, and
Community Development, 8(1), 13-19. https://doi.org/10.5304/jafscd.2018.081.016

Copyright (C 2018 by the Authors. Published by the Lyson Center for Civic Agriculture and Food Systems. Open access under CC BY license.

\begin{abstract}
Visiting farms and ranches to experience agriculture and celebrate harvests is an age-old tradition. In the U.S. and many other countries, this tradition is the basis of an emerging industry known as "agritourism." Although agritourism appears to be growing in many parts of the U.S., confusion about agritourism limits the ability of researchers and

\footnotetext{
a * Corresponding author: Lisa C. Chase, University of Vermont Extension; 130 Austine Drive, Suite 300; Brattleboro, Vermont 05301 USA; +1-802-257-7967; lisa.chase@uvm.edu

b Oregon State University Extension Service; 1320 Capitol St. NE, Suite 110; Salem, Oregon 97301 USA; +1-503-891-4103; mary.stewart@oregonstate.edu
}

c Rutgers University, Department of Agricultural, Food and Resource Economics; 55 Dudley Road; New Brunswick, New Jersey 08901 USA; +1-848-932-9127; brischi@sebs.rutgers.edu agricultural interests to fully understand this sector's economic importance and to support its performance over time. A universal understanding of agritourism is needed for clear communication, reliable and consistent measurement, informed policies, and programs that support farms and ranches and their communities. To that end, the authors present a conceptual framework that incorporates core and peripheral tiers, as well as five categories of activities, including direct sales, education, hospitality, outdoor recreation, and entertainment. The goal of this viewpoint is to stimulate

\footnotetext{
d Mississippi State University Extension; Department of Agricultural Economics; 372 Lloyd Ricks Watson; Mississippi State, MS 39762 USA; becky.smith@msstate.edu

e Michigan State University Extension; 319 Court Street; Sault Ste. Marie, Michigan 49783 USA; +1-906-635-6368; walkmich@msu.edu
} 
commentary and debate that furthers our collective understanding of agritourism as it becomes an increasingly important industry in the U.S.

\section{Keywords}

Agritourism; Agrotourism; Agritainment; Culinary

Tourism; Direct Sales; Farm-Based Education; Farm Stands; Farm Stays; Farm Tourism; ValueAdded Agriculture

\section{Introduction}

Consumer demand for local food and experiences on farms and ranches has led to rapid increases in "agritourism" across the U.S. It has also led to a myriad of different understandings of the concept of agritourism and estimates of its value to farms and ranches, as well as to communities. Schilling, Sullivan, and Komar (2012) note that there is neither a standard definition of agritourism, nor agreement on the types of activities that constitute it. This was also noted by Busby and Rendle (2000) when they identified 13 unique definitions of agritourism, based on a review of existing academic literature, and by Arroyo, Barbieri, and Rich (2013) when they surveyed farmers, Cooperative Extension faculty, and residents of Missouri and North Carolina about their perceptions of agritourism.

There is some agreement that agritourism refers to "farming-related activities carried out on a working farm or other agricultural settings for entertainment or education purposes" (Arroyo et al., 2013, p. 45). However, disagreement exists regarding the boundaries and characteristics of agritourism, including the setting, types of experiences, authenticity, and importance of tourism (Streifeneder, 2016). Some researchers maintain that agritourism must take place on a working farm, while others include nonworking farms as well as farmers markets and agricultural fairs. The connection to agriculture and the engagement of visitors is also an issue, leading to policy controversies over whether activities on farms that have little to do with agriculture should be included, such as weddings and outdoor recreation like mountain biking. Only a limited portion of an agritourism typology proposed by Phillip, Hunter, and Blackstock (2010) was found to be acceptable to survey respondents in Missouri and North
Carolina (Arroyo et al., 2013). Streifeneder (2016) makes the case for European agreement on the characteristics of "authentic agritourism," which encompasses only a small portion of Phillip et al.'s typology. This disagreement over the boundaries of agritourism has hindered the ability of researchers and agricultural interests to fully understand the sector's economic importance and develop programming to support its performance over time.

The purpose of this paper is to provoke discussion and debate about the boundaries of agritourism with the ultimate goal of developing a conceptual framework that is widely accepted in the U.S. Should agritourism be restricted to onfarm activities that are deeply connected to agriculture, or should the concept be broader? How important is tourism as part of the definition? And what does authenticity mean in this context? The authors collaborated to develop a conceptual framework based on the literature and further reviewed by colleagues throughout the U.S. The framework encompasses core and peripheral tiers, as well as five categories of activities that include direct sales, education, hospitality, outdoor recreation, and entertainment. We invite colleagues to respond with their viewpoints to spur discourse in an evolving and important sector of agriculture in the U.S and other countries.

\section{The Emergence of Agritourism}

Although the term agritourism is relatively new in the U.S., visiting farms and ranches to learn about agriculture and celebrate harvests is a long-standing tradition. Early precursors to the modern concept of agritourism are evident in the movements of Native American tribes across long distances to participate in planting and harvesting feasts and ceremonies. Throughout the 19th century, Europeans immigrating to the U.S. brought similar agrarian traditions and religious and cultural holidays with them to prepare for spring planting and celebrate harvest time. In the latter part of the century, many large farmhouses served as country inns, where migrants traveling westward would spend their nights at farms along their route, paying or working for room and board. In the late 1800s, as the U.S. became increasingly urbanized, families living in cities would visit farms or ranches 
to escape city life and learn about farming and rural life. About the same time, dude ranches in the American West began to attract wealthy Easterners and Europeans on hunting trips and sightseeing excursions. By the 1920s and 1930s, dude ranches were a major tourist attraction in the Rocky Mountain area of North America (Chase \& Grubinger, 2014).

Farm and ranch stays continue to be popular in the U.S. and in many European countries. The term "agritourism" used in the U.S. likely originated from the Italian National Legal Framework for Agritourism passed in 1985. This law encourages overnight farms stays, or agriturismo, as a way for Italian farmers to diversify their income so they can maintain farming practices, landscapes, and agricultural buildings. Agriturismo has become increasing popular in Tuscany, Italy, and many other places around the globe where agritourism and culinary tourism complement each other. In some parts of the world, production of specific types of food and drink are the crux of agritourism in that region. In Europe, protected designation of origin (PDO), protected geographical indication (PGI), and traditional specialties guaranteed (TSG) require that the names and labels of certain foods and drinks can only be used when they are produced in a specific region, sometimes following specific protocols. Well known examples include Champagne and Cognac in France, and Asiago, Gorgonzola, and Parmigiano-Reggiano cheeses in Italy (Chase, 2017). These strategies are gaining momentum in parts of the U.S. For example, California's success in attracting visitors to wine tastings at vineyards in Sonoma and Napa counties has been extended to artisanal cheese trails, beer trails, and tourism involving other value-added specialty products.

While the agritourism industry appears to be flourishing in practice, confusion over the concept has resulted in difficulties understanding this emerging industry. Research, policy, and programs to support agritourism have been hindered by inconsistency in definitions and lack of an agreedupon framework (Arroyo et al., 2013; Flanigan, Blackstock, \& Hunter, 2015). Measuring the agritourism industry has been especially challenging.
Efforts to Measure Agritourism in the U.S. Anecdotal accounts, including the Extension programming experiences of the authors, clearly suggest that the income opportunities agritourism presents to farmers can be significant. Therefore, tracking the economic health of this sector is important, as it can serve to justify the commitment of time and resources to policy development, Extension programming, and other efforts to bolster farm economic viability. However, data series that support systematic assessments of the nation's agritourism sectorand its contributions to the broader agricultural industry — are limited. Similarly, there is variability in the definition and scope of agritourism represented in state and substate level research, limiting cross-state and longitudinal tracking of the sector's performance and evolution (Busby \& Rendle, 2000; Phillip et al., 2010; Schilling et al., 2012).

In the 2002 Census of Agriculture, the U.S. Department of Agriculture (USDA) National Agricultural Statistics Service (NASS) expanded the collection of data on income from farm-related sources to include, for the first time, income from "recreational services." The census form instructions provided as examples "hunting, fishing, etc." The 2007 and 2012 censuses adopted revised terminology, "agri-tourism and recreational services," that was accompanied by a wider range of example activities, "such as farm or winery tours, hay rides, hunting, fishing, etc." Nevertheless, the census definition of agritourism remains narrowly constructed in comparison to other definitions used in agritourism literature and academic studies. Van Sandt and Thilmany McFadden (2016) examined agritourism trends using the limited NASS definition of "agri-tourism and recreational services" for national trends and comparisons, but then expanded that definition to include direct sales, accommodations, entertainment and/or events, outdoor recreation, and educational activities for a survey of agritourism farms in Colorado and California. These five categories of agritourism are consistent with statewide surveys conducted by NASS in collaboration with land-grant university researchers in New Jersey and Vermont (New England 
Agricultural Statistics Service, 2001, 2004; Schilling et al., 2012).

Symptomatic of the inconsistencies in terminology and definition, the Census of Agriculture limits its definition of direct-to-consumer sales by including only products consumed (eaten) by people. The Census of Agriculture has collected data on the "value of agricultural products sold directly to individuals for human consumption" (emphasis added) since 1997. In other words, the Census definition excludes non-edibles (e.g., Christmas trees, cut flowers, nursery stock). Valueadded products (e.g., jams, wine, cheese), which are often important components of a farm's retail product mix, are also excluded. Further confounding measurement, the "value of agricultural products sold directly to individuals" includes farmers markets and other direct-to-consumer sales that take place off the farm.

Despite these limitations, Census of Agriculture data are the most accessible and widely used metrics for measuring the growth and performance of agritourism enterprises in the U.S. According to the 2012 Census, combined income from agritourism and recreational services and direct-toconsumer sales (hereafter referred to as agritourism sales for simplicity) totaled US $\$ 2.01$ billion. It is difficult to accurately monitor agritourism sales over time due to the change in terminology after the 2002 census.

Table 1 presents combined direct marketing sales and agritourism income ("agritourism sales") reported in the Censuses of Agriculture of 2002, 2007, and 2012. Nationally, combined income from these activities rose from US $\$ 1.01$ billion to US $\$ 2.01$ billion over the past decade. Growth in income in the 2002-07 period was 75.3 percent, as compared to 13.3 percent growth in the 2007-12 period. Similar disparities in growth rates are observed in each census region, ranging from a 3.5fold differential in period growth rate (in the Northeast) to a 13.3 -fold difference (in the

Table 1. Agritourism and Direct Marketing Income Reported in the 2002, 2007, and 2012 Censuses of Agriculture

\begin{tabular}{|c|c|c|c|c|c|}
\hline & \multicolumn{3}{|c|}{$\begin{array}{c}\text { Agritourism sales, by source } \\
\text { (US\$ million) }\end{array}$} & \multirow{2}{*}{$\begin{array}{c}\% \text { chg. } \\
2002-2007\end{array}$} & \multirow{2}{*}{$\begin{array}{l}\text { \% chg. } \\
2007-2012\end{array}$} \\
\hline & 2012 & 2007 & 2002 & & \\
\hline \multicolumn{6}{|l|}{ MIDWEST } \\
\hline Total Agritourism Sales & 417.8 & 397.4 & 236.8 & 67.9 & 5.1 \\
\hline Agri-tourism and Recreational Services & 111.2 & 96.7 & 29.2 & 231.7 & 15.0 \\
\hline Direct Marketing & 306.6 & 300.8 & 207.6 & 44.9 & 2.0 \\
\hline \multicolumn{6}{|l|}{ NORTHEAST } \\
\hline Total Agritourism Sales & 481.8 & 395.9 & 225.4 & 75.6 & 21.5 \\
\hline Agri-tourism and Recreational Services & 104.7 & 77.0 & 9.5 & 714.5 & 35.9 \\
\hline Direct Marketing & 377.1 & 318.9 & 216.0 & 47.4 & 18.3 \\
\hline \multicolumn{6}{|l|}{ SOUTH } \\
\hline Total Agritourism Sales & 549.6 & 467.1 & 277.4 & 68.4 & 17.7 \\
\hline Agri-tourism and Recreational Services & 274.6 & 251.1 & 160.9 & 85.5 & 27.1 \\
\hline Direct Marketing & 275.0 & 251.1 & 160.9 & 56.1 & 9.5 \\
\hline \multicolumn{6}{|l|}{ WEST } \\
\hline Total Agritourism Sales & 564.7 & 517.7 & 274.8 & 88.3 & 9.1 \\
\hline Agri-tourism and Recreational Services & 213.6 & 177.1 & 47.1 & 276.0 & 20.6 \\
\hline Direct Marketing & 351.1 & 340.5 & 227.7 & 49.5 & 3.1 \\
\hline \multicolumn{6}{|l|}{ UNITED STATES } \\
\hline Total Agritourism Sales & $2,013.9$ & $1,778.1$ & $1,014.4$ & 75.3 & 13.3 \\
\hline Agri-tourism and Recreational Services & 704.0 & 566.8 & 202.2 & 180.4 & 24.2 \\
\hline Direct Marketing & $1,309.8$ & $1,211.3$ & 812.2 & 49.1 & 8.1 \\
\hline
\end{tabular}


Midwest). Much of the variability in growth rates observed across periods stems from very large increases in income reported from "agri-tourism and recreational services" between 2002 and 2007, particularly in the Northeast, Midwest, and West. Growth in direct marketing sales, which is a longer and more established time series in the Census of Agriculture, was more modest in all four regions in both reporting periods.

These marked differences in income growth across the two five-year periods raise the question of whether these metrics capture actual growth in agritourism sales, reflect enumeration problems associated with a relatively new area of inquiry in the census, or some combination of both. The change in terminology ("recreational services" to "agri-tourism and recreational services") and the expanded list of representative activities used to exemplify the terms may reasonably be expected to limit comparability across periods. These inconsistencies in definitions related to measurement exemplify the need to establish both standardized terminology and a clearer sense of the activities commonly associated with agritourism.

\section{Developing a Conceptual Framework for Agritourism}

With the goal of creating a widely accepted conceptual framework for understanding agritourism, Figure 1 illustrates two suggested tiers of activities (core and peripheral), where core activities are generally accepted as agritourism while peripheral activities may be controversial. Under this conception of agritourism, an activity is defined as being either core or peripheral on the basis of location (i.e., on-farm vs. off-farm), or the relative degree to which that activity is connected to agriculture. Core activities take place on a working farm or ranch and have deep connections to agricultural production and/or the marketing of a farm's products. These include direct farm sales of agricultural products sold on the farm through farmstands and U-pick. Also included in core activities are experiences that take place on the farm and are deeply connected to agricultural production, such as farm tours, farm-to-table meals, overnight farm stays, and agricultural festivals on farms.

In contrast, peripheral activities lack a deep connection to agricultural production, even though they may take place on a working farm or ranch. For example, the farm may serve as the venue (or setting) for events, such as weddings, concerts, hiking, and biking. Another type of peripheral activity is one that is closely connected to agriculture but does not take place on a working farm or ranch, such as farmers markets and agricultural fairs. The question of whether these peripheral activities should be considered agritourism has become controversial in certain circumstances. These are questions that deserve careful consideration, since measurement, policy, and programming are significantly impacted by the answers.

Regardless of whether an activity is considered core or peripheral, it can be classified into one or more categories commonly associated with agritourism: direct sales, education, hospitality,

\section{Figure 1. Core and Peripheral Tiers of Activities that May Be Considered Agritourism}

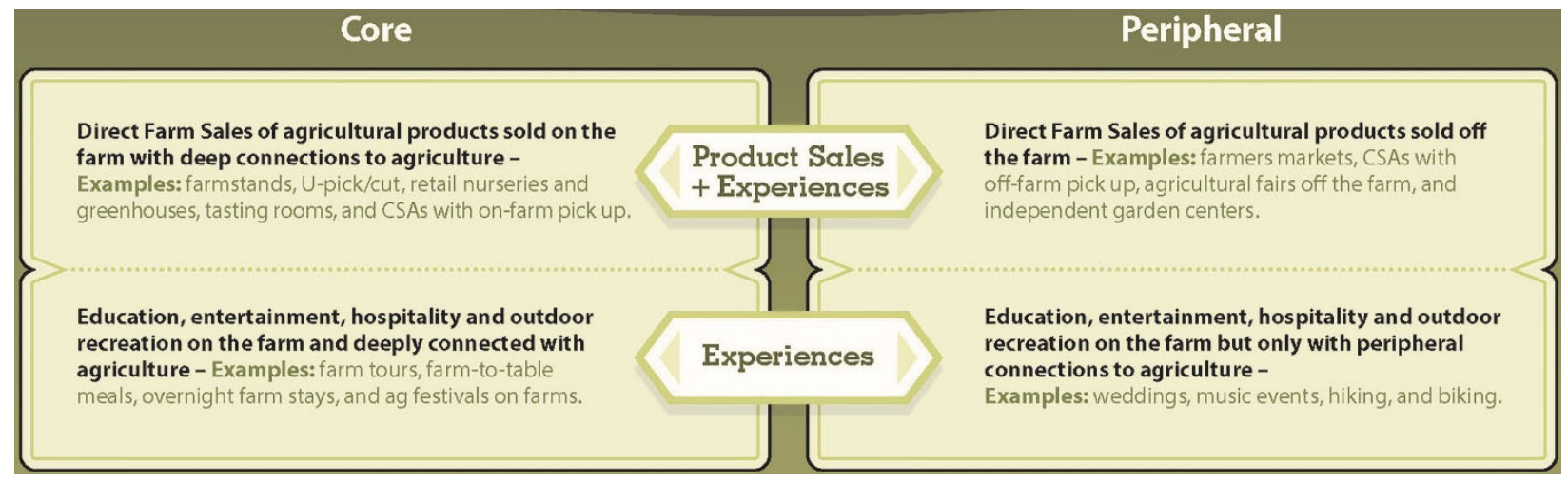


Figure 2. Five Categories of Agritourism including Direct Sales, Education, Hospitality, Outdoor Recreation, and Entertainment, and Examples of Core vs. Peripheral Activities

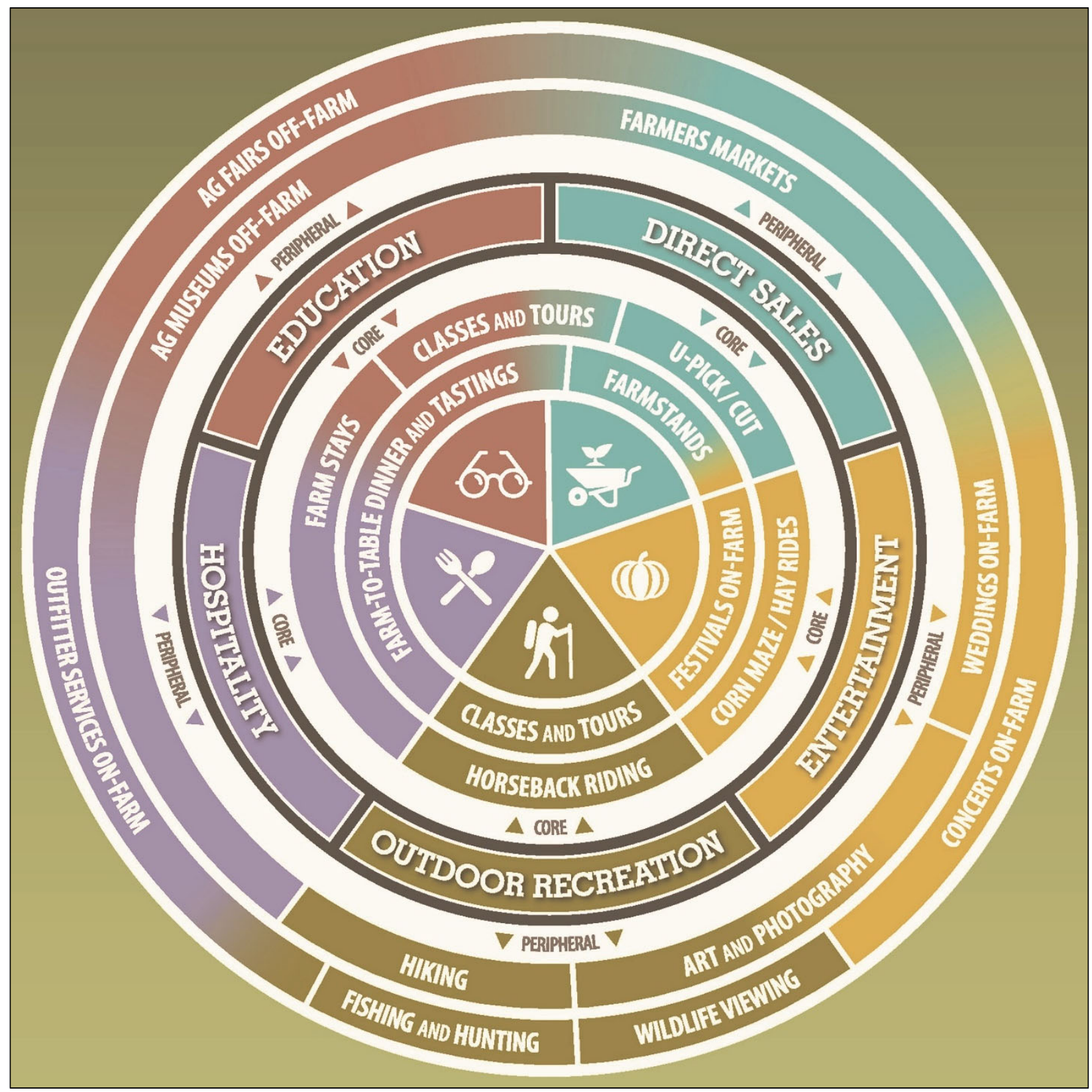

outdoor recreation, and entertainment. The activities on the inner part of the wheel shown in Figure 2 are considered core, and those on the outer part are considered peripheral. As the wheel illustrates, activities may fall into multiple categories. For example, farm-to-table dinners and tastings span three categories: direct sales, education, and hospitality.

\section{Conclusions}

The term "agritourism" is understood in different ways throughout the U.S. and the world. This can create confusion and conflict with respect to communication, measurement, policy, and programs that support this emerging industry. While operational definitions may be applied to specific situations, there is a need for a common 
understanding of agritourism, notwithstanding all of its complexity. To that end, a team of Cooperative Extension faculty developed a conceptual framework that incorporates five categories of activities, including direct sales, education, hospitality, outdoor recreation, and entertainment, as well as core and peripheral tiers.

The conceptual framework presented in this article is not intended to be the final word. Rather, it is meant to encourage discussion, debate, and deliberation as we continue to improve our understanding of the agritourism industry. Is there general agreement throughout the U.S. on the core activities that constitute agritourism? Should peripheral activities be included in agritourism or be given alternative labels, such as "countryside tourism," as suggested by Streifeneder (2016)? How is authenticity understood with respect to agritourism, and what is the role of travel and tourism? These questions, and more, require careful consideration. The hope is that this viewpoint will stimulate discourse and progress toward the ultimate goal of a common understanding of agritourism in the U.S.

\section{Acknowledgments}

The authors would like to thank several colleagues who reviewed portions of the manuscript and provided feedback representing different perspectives on agritourism in different part the U.S., including Becky Bartlett and Vera Simon-Nobes from Vermont, Holly George and Penny Leff from California, Cynthia Messer from Minnesota, Dee Singh-Knights from West Virginia, and Stacy Tomas from Oklahoma. Erik Simmons from Oregon State University Extension Service designed the graphics in Figures 1 and 2.

\section{References}

Arroyo, C. G, Barbieri C., \& Rich S. R. (2013). Defining agritourism: A comparative study of stakeholders' perceptions in Missouri and North Carolina. Tourism Management, 37(August), 39-47.

https://doi.org/10.1016/j.tourman.2012.12.007

Busby, G., \& Rendle, S. (2000). The transition from tourism on farms to farm tourism. Tourism Management, 21(6), 635642. https://doi.org/10.1016/S0261-5177(00)00011-X

Chase, L. C. (2017). Agritourism. In L. Lowry \& J. G. Golson (Eds.), The SAGE international encyclopedia of travel and tourism. Thousand Oaks, California: SAGE Publications.

Chase, L., \& Grubinger, V. (2014). Food, farms, and community: Exploring food systems. Lebanon, New Hampshire: University Press of New England.

Flanigan, S., Blackstock, K., \& Hunter, C., (2015). Generating public and private benefits through understanding what drives different types of agritourism. Journal of Rural Studies, 41(October), 129-141. https://doi.org/10.1016/j.jrurstud.2015.08.002

New England Agricultural Statistics Service. (2001). Vermont agri-tourism 2000. Retrieved from http://www.uvm.edu/ tourismresearch/agtour/publications/VT\%20Agritourism $\% 202000 \% 20$ Fact $\% 20$ Sheet.pdf

New England Agricultural Statistics Service. (2004). Vermont agri-tourism 2002. Retrieved from http://www.uvm.edu/ tourismresearch/agritourism/publications/VT\%20Agritourism $\% 202002 \% 20 \mathrm{Fact} \% 20$ Sheet.pdf

Phillip, S., Hunter, C., \& Blackstock, K. (2010). A typology for defining agritourism. Tourism Management, 31(6), $754-758$. http://doi.org/10.1016/j.tourman.2009.08.001

Schilling, B. J., Sullivan, K. P., \& Komar, S. J. (2012). Examining the economic benefits of agritourism: The case of New Jersey. Journal of Agriculture, Food Systems, and Community Development, 3(1), 199-214. http://doi.org/10.5304/jafscd.2012.031.011

Streifeneder, T. (2016). Agriculture first: Assessing European policies and scientific typologies to define authentic agritourism and differentiate it from countryside tourism. Tourism Management Perspectives, 20(October), 251-264. https://doi.org/10.1016/j.tmp.2016.10.003

Van Sandt, A., \& Thilmany McFadden, D. (2016). Diversification through agritourism in a changing U.S. farmscape. Western Economics Forum, 15(1), 52-58. http://purl.umn.edu/253469 